\title{
Growth Comparison of Young Three Agarwood Producing Species Intercropped with Rubber under Different Light Conditions
}

\author{
Lanka M.P.D. ${ }^{*}$, Subasinghe S.M.C.U.P. ${ }^{1}$, Senevirathna A.M.W.K. ${ }^{2}$ and \\ Nayanakantha N.M.C. ${ }^{3}$ \\ ${ }^{1}$ Department of Forestry and Environmental Science, University of Sri Jayewardenepura, Sri Lanka \\ ${ }^{2}$ Department of Export Agriculture, Uva Wellassa University, Sri Lanka \\ ${ }^{3}$ Department of Plant Science, RRI, Agalawatta, Sri Lanka \\ *mpdlanka@gmail.com
}

\begin{abstract}
Sri Lankan rubber industry is facing severe challenges due to the presence of relatively cheaper synthetic rubber, poor quality lands, high labour cost and white root disease epidemic. Rubber Research Institute of Sri Lanka (RRISL) has found intercropping of short rotation commercial crops with rubber as a solution for these problems. Agarwood producing species of family Thymalaeaceae are suitable crops for this reason as those can be rotated about three times in a 30 year lifespan of a rubber plantation. Those species form a highly valuable resin due to a self-defense mechanism which can be induced artificially inside the stem. Therefore the present study was conducted to identify the most suitable agarwood producing species to be intercropped with rubber under different light conditions.

A field trial was established in RRISL premises of Dartonfield, Agalawatte for this reason. Three agarwood producing species; Aquilaria crassna, A. subintegra and Gyrinops walla were intercropped with rubber clone RRIC 121 planted in single and double row systems. The first two have recently been introduced to Sri Lanka and G. walla is native to the country. Agarwood species planted at $3 \mathrm{~m}$ intervals in these intercropping systems were exposed to full sunlight and 50\% artificial shade. Stem diameter at $30 \mathrm{~cm}$ above the ground and total height were taken as the growth measurements at monthly intervals for 15 months. Growth at the end of each three month period was compared using one-way ANOVA using Minitab software.

According to the results, both diameter and height were not significantly different for all three species when grown in 50\% shade or under full sun. However, both diameter and height growth of Gyrinops walla was significantly lower than A. crassna and A. subintegra when grown under full sun and $50 \%$ shade in both single and double row systems of rubber at the $14^{\text {th }}$ month. Apart from the height growth at the $14^{\text {th }}$ month under full sun of double row system, significant differences were not observed for both diameter and height between A. crassna and $A$. subintegra for all above treatments. Therefore it is evident that the growth of $G$. walla which is native to Sri Lanka is lower even at the early stage than the introduced two agarwood producing species.
\end{abstract}

Keywords: Gyrinops walla, Agarwood producing species, Intercropping, Rubber

Proceedings of the International Forestry and Environment Symposium 2016, Department of Forestry and Environmental Science, University of Sri Jayewardenepura, Sri Lanka. 